\title{
“DEIXA O MENINO RODAR": O CARISMA RETETÉ EM UMA IGREJA PENTECOSTAL DA PERIFERIA
}

\section{Réia Silvia Gonçalves Pereira ${ }^{1}$}

\begin{abstract}
Resumo: No artigo, são apresentados dados etnográficos da igreja Herdeiros do Sião, pequena igreja pentecostal localizada numa favela de Vitória, Espírito Santo. Em observação participante empreendida de janeiro a abril de 2014 e retomada entre janeiro e fevereiro de 2018, apresento pontos de reflexáo sobre a singularidade da expressão religiosa representada pela denominação, que pode ser associada a uma vertente pentecostal conhecida, em expressão de grupo, como reteté de Jeová. $\mathrm{O}$ termo se refere aos rituais de culto ao espírito santo marcados pelo caráter extático, sensorial e pela intensidade das performances corporais, que lembram uma dança giratória. Especificamente, no artigo, a análise se concentra na reflexáo sobre como a Herdeiros do Sião se situa e atua no contexto da favela onde está inserida. Em sentido mais amplo, partindo do conceito sobre afinidade eletiva (Weber, 2004) e posição fronteiriça (Coleman, 2006), argumento que os rituais vivenciados na igreja, bem como sua forma de organização, fornecem pistas sobre a associação entre a ritualística reteté e o ethos periférico. Nesta esteira, também são discutidas as disputas por legitimidade da religiosidade reteté, muitas vezes invisibilizadas ou desconsideradas dentro do campo evangélico brasileiro.
\end{abstract}

Palavras-chave: Pentecostalismos; Periferias; Ritual.

"LET THE BOY SPIN": THE "RETETÉ" CHARISMA IN A PENTECOSTAL CHURCH OF THE SUBURBS

Abstract: This article presents ethnographic data from Herdeiros do Siáo, a little
pentecostal church situated in a slum in Vitória, Espírito Santo. In a participant
observation carried out from January to April 2014 and resumed between January
and February 2018, I present points of reflection about the singularity of the
religious expression represented by this denomination, which can be associated

${ }^{1}$ Doutoranda em Ciências Sociais pela Universidade Federal de Juiz de Fora. E-mail: artigodebates@gmail.com.

Debates do NER, Porto Alegre, ANo i9, N. 36, P. 267-305, Ago./Dez. 20 i 9 
to a pentecostal branch known, in an expression used by the group, as "reteté de Jeová". The term refers to the rituals of the cult to the Holy Spirit marked by the ecstatic, sensory character and by the intensity of the corporal performances, which remind us of a whirling dance. In this article, the analysis focuses on the reflection about how Herdeiros do Sião situates itself and acts in the context of the slum. In a broader sense, based on the concept of elective affinity (Weber, 2004), I argue that the rituals experienced at Herdeiros do Sião, as well as its form of organization, suggest an association between the reteté rituals and the peripheral ethos. Disputes for the legitimacy of reteté religiosity are also discussed, as it is often made invisible or disregarded by the evangelical field, precisely for its association with the Brazilian peripheral universe.

Keywords: Pentecostalisms; Suburbs; Ritual.

\section{INTRODUÇÃO}

Quem tocar no crente ungido, vai com a cara na poeira

(Damares)

Para o artigo, apresento dados etnográficos da Herdeiros do Sião, igreja pentecostal localizada numa favela (Valladares, 2008) de Vitória, Espírito Santo. Morei na localidade em virtude da pesquisa de mestrado, de janeiro a abril de 2014, retornando ao campo em janeiro de 2018. Além dessa igreja, durante todo o tempo de pesquisa, participei de cultos em muitas outras denominações de características semelhantes à Herdeiros de Sião. Eram pequenas igrejas pentecostais, formando grupos com número relativamente reduzido de integrantes e com intenso controle sobre as condutas de seus membros. A partir dessas observaçóes, apresento algumas reflexôes neste texto.

Como estratégia textual, o trabalho está dividido em dois tópicos principais. No primeiro deles, a análise tem como base a experiência etnográfica na igreja Herdeiros do Sião. No segundo item, apresento pontos de reflexão sobre a singularidade das práticas religiosas da igreja estudada, associando tais experiências a uma expressão de religiosidade muito comum nos bairros das

Debates do NER, Porto Alegre, ano i9, N. 36, P. 267-305, Ago./Dez. 20 i9 
camadas populares urbanas conhecidas, em expressão de grupo, como reteté de Jeová. O termo alude, de modo geral, aos rituais ruidosos e sensoriais, marcados por expressivas performances corporais que lembram uma dança giratória (Guerreiro, 2016, 2018). Desta feita, a partir das observaçóes na Herdeiros do Sião, o reteté será abordado por sua inexorável imprecisão classificatória, revelando a complexidade das experiências pentecostais vivenciadas nas periferias.

\section{A HERDEIROS DO SIÁO E O BAIRRO SÃO PEDRO: AS IGREJAS DE FOGO E AS CAMADAS POPULARES}

Pequena e localizada em um espaço adaptado de um estabelecimento comercial, a Herdeiros do Sião é uma entre tantas outras igrejas pentecostais presentes no bairro São Pedro, uma favela (Valladares, 2008) situada na região Noroeste de Vitória, Espírito Santo. Como afirmado, morei no bairro entre janeiro e abril de 2014, retornando à localidade no período que compreende janeiro e fevereiro de 2018.

Compondo um complexo de favelas, a região de São Pedro está subdividida em seis áreas, formando os bairros de São Pedro I, II, III, IV e V, além do Morro Conquista. Cortada por uma rodovia, abriga ao longo da estrada um intenso centro comercial (Pereira, 2014). Especificamente, residi em uma das subdivisóes de São Pedro, aos pés do Morro Conquista, considerada a área mais carente da regiáo.

$\mathrm{Na}$ localidade, as casas geminadas, algumas em madeira, não tinham quintais; formavam becos que estreitavam as já afuniladas ruas, numa conformação próxima ao que Oosterbaan (2009) denominou como "densidade das favelas" (Oosterbaan, 2009, p. 82; Pereira, 2018). 
Figura 1 - Beco do Morro Conquista

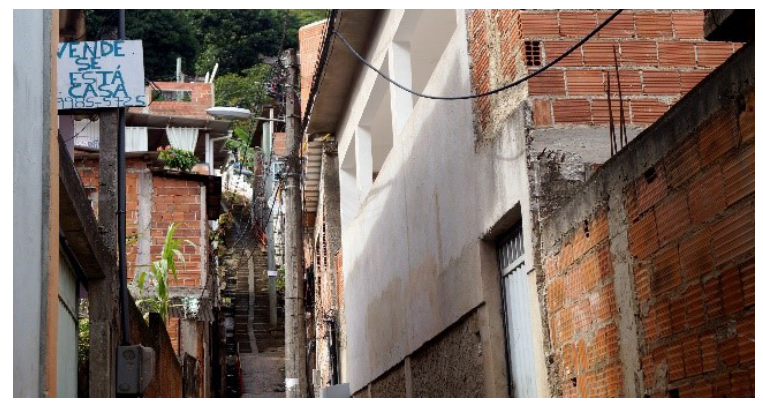

Fonte: Acervo da autora.

Foi ao andar por essas ruas de São Pedro que notei a presença das pequenas igrejas pentecostais. Eram notáveis tanto pela variedade quanto pela diversidade de seus nomes. Olaria de Deus, Semente de Deus na Terra e Adonay eram algumas das igrejas que encontrei apenas no quarteiráo da minha casa. Mesmo em sua variedade, guardavam semelhanças: eram pequenas, geralmente localizadas em espaços destinados às garagens, com portas de alumínio de correr. Também chamava a atenção a expressividade sonora de seus cultos. Em tais igrejas, as oraçóes e os hinos religiosos eram destacadamente ruidosos, podendo ser ouvidos a significativa distância dos templos. Na diversidade religiosa do Morro Conquista, a amplitude dos sons produzidos pelos rituais das pequenas igrejas pentecostais parecia ser um fator valorizado por tais denominaçóes. 
Figura 2 - Igreja Adonay Shalon

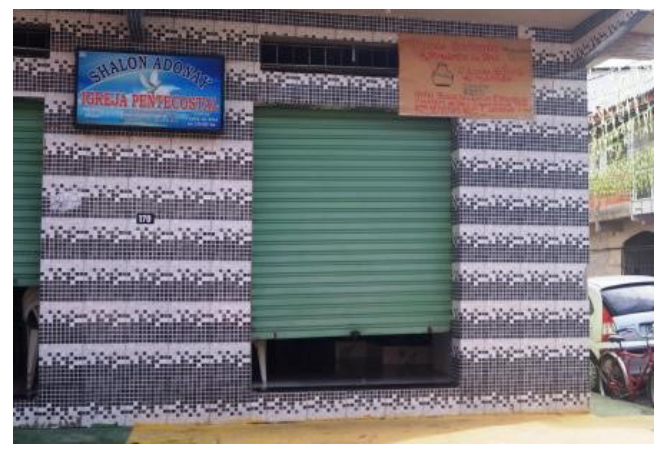

Fonte: Acervo da autora.

Figura 3 - Igreja Olaria de Deus

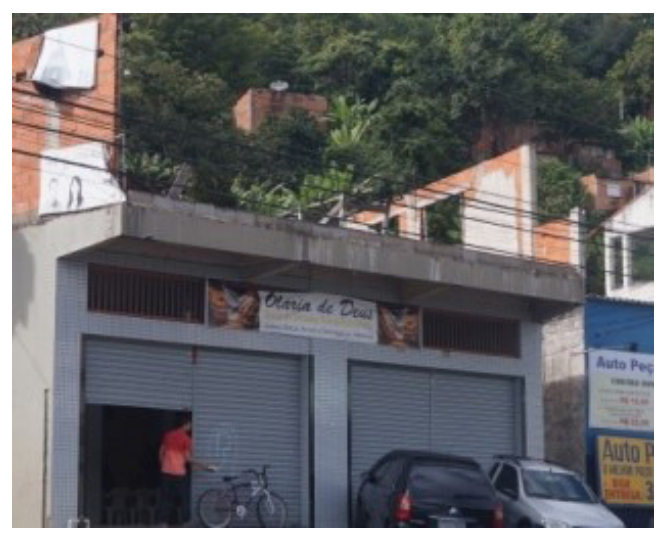

Fonte: Acervo da autora.

Especificamente sobre a Herdeiros do Sião, devo dizer que é uma igreja como tantas outras localizadas na favela. Pequena. Contava com um pequeno altar e um púlpito. As cadeiras eram de plástico e não havia equipamentos de ventilação. Também não havia gravuras ou esculturas. 
Figura 4 - Fachada da Herdeiros do Sião

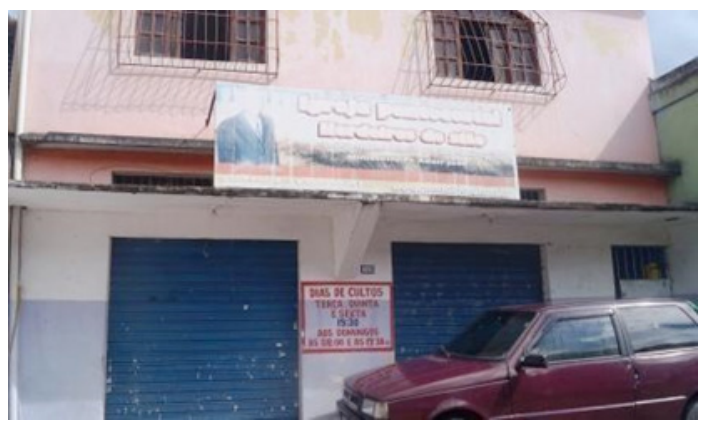

Fonte: Acervo da autora.

$\mathrm{Na}$ denominação, conheci a pastora Cláudia ${ }^{2}$, uma mulher negra, altiva, com cerca de 50 anos. Voz potente, exalava autoridade. Viúva com cinco filhos, Cláudia morava em uma pequena casa vizinha à igreja, sendo uma das poucas integrantes que sabia ler as passagens bíblicas com desenvoltura. Mesmo com o ar severo, a pastora surpreendentemente fora bastante atenciosa. Apresentou-me aos demais integrantes, comentava sobre casos que considerava "interessantes" para apresentar na pesquisa, embora tenha confessado que "crente não combina com faculdade".

Sobre os demais integrantes - cerca de 20, segundo informação da pastora -, notei que as mulheres formavam a maioria dos fiéis da igreja. Em minhas conversas com algumas delas, percebi que eram mães; pelo menos cinco delas tinham filhos encarcerados. Tive contato mais próximo com Glória $^{3}$, viúva de 37 anos, com um filho encarcerado e uma filha, namorada de um integrante do narcotráfico.

Participei de alguns rituais da Herdeiros do Sião, dentre eles, uma campanha de cura e libertação (Mafra, 1999). Na maioria das celebraçóes observadas em 2014, notei que todos podiam se manifestar e o faziam por meio de "exaltaçóes orais" (Pereira, 2014). Seguiam até a frente da igreja,

${ }^{2}$ Nome fictício escolhido pela interlocutora.

3 Nome fictício escolhido pela interlocutora.

Debates do NER, Porto Alegre, ANo i9, N. 36, P. 267-305, Ago./Dez. 20 i9 
usavam o microfone e diziam algum relato, muitos deles sobre situaçóes aflitivas (Duarte, 1988), como as relacionadas ao encarceramento dos filhos, tais relatos são chamados testemunhos (Birman; Machado, 2012; Dullo, 2016). Em 2018, contudo, um outro tema marcava as campanhas: o desemprego. Percebi, náo apenas na Herdeiros do Siáo, como em outras igrejas de caráter semelhante, o quanto o temor pela privação devido à falta de emprego enseja a realização de campanhas.

Nos cultos da igreja, a música tinha um papel importante. Cada louvor era acompanhado por um hino, cantado com exaltação pelo fiel. Glória, uma das minhas mais próximas interlocutoras de campo, também apresentou seu louvor lembrando que orava pelo filho encarcerado por tráfico de drogas e pela filha, namorada de um também traficante. Cantava uma música em tom bem alto e, naqueles momentos, parecia não se preocupar com afinação. Trago alguns trechos:

Quando estiver frente ao mar

e não puder atravessar,

chame este homem com fé,

só ele abre o mar.

Não tenha medo,

irmão, se atrás vem Faraó,

Deus vai te atravessar

e você vai entoar

o hino da vitória.

Toda vez que o Mar Vermelho tiver que passar

chame logo este Homem para te ajudar,

é nas horas mais difíceis que ele mais te vê,

pode chamar este Homem que ele tem poder

(Cassiane, "Hino da vitória") ${ }^{4}$

${ }^{4}$ HINO da vitória. [S. l.: s. n.], 2007. 1 vídeo (ca. 3 min). Publicado pelo canal Simone Maximo. Disponível em: https://www.youtube.com/watch?v=iW4KMdtJoww. Acesso em: 2 set. 2019.

Debates do NER, Porto Alegre, ano i9, N. 36, P. 267-305, Ago./Dez. 2019 
Além do louvor de Glória, com o tempo, outras narrativas se sucederam e se transformaram em exaltaçôes, sempre em tom combativo. Os gritos e os cânticos eram estimulados e entravam em um movimento ascendente. Aquele era o momento do avivamento (Csordas, 1999), quando ocorrem as manifestações do espírito santo. Naquele instante, alguns choravam, muitos gritavam, outros se debatiam como se recebessem uma descarga elétrica. Notei que as performances pareciam ser individuais, porém ritmadas. Cada pessoa manifestava-se de forma diferente. Alguns integrantes balançavam os braços, outros se contorciam e alguns pareciam rodar como uma dança giratória.

Prestei atenção (Forsey, 2010) ao ritmo do som entoado. Não era um ritmo lamurioso. Ao contrário, com o toque de um pandeiro, a cadência parecia lembrar a batida do forró. Era um ritmo quase dançante (Bourcier, 2006). Assim, longe de lembrar o ascetismo racional protestante narrado por Weber (2004), do qual o pentecostalismo é filho, havia um inegável espirito sobrenatural naqueles cultos. Dessa forma, o caráter extático e emocional do ritual era evidente.

Ao participar dos rituais da Herdeiros do Sião, uma das muitas igrejas pentecostais que povoavam Conquista, coloco em perspectiva as conceituaçóes de Mariza Peirano (2002, 2014), ao argumentar que a análise do evento ritual é importante justamente por evidenciar em uma escala hiperbolizada a instância do usual e do cotidiano. Diz a autora sobre a relação entre rituais e cotidiano: "[...] estamos, portanto, lidando com fenômenos semelhantes em graus diversos" (Peirano, 2002, p. 8).

Nessa esteira, por meio dos rituais da Herdeira em Sião, as aflições de Glória, que clamava pelo filho preso por narcotráfico, instância que media a maioria das relaçóes de Conquista, puderam ser narradas. As preces exaltadas e ruidosas, cujos "O êxtase e a presença física do espírito, compartilhado por outros que também conhecem ou dividem seus problemas, talvez sejam a maior expressão dessa 'vitória"' (Pereira, 2014, p. 98).

Assim, em consonância com Peirano (2002), reitero a importância da análise da religiosidade praticada na Herdeiros do Sião, não apenas por seu 
aspecto ritualístico, mas também em seu aspecto contextual. Advogo que essa forma de religiosidade diz respeito também a seu modo organizativo, como mencionado, geralmente, em pequenas comunidades religiosas nas periferias.

Sobre a própria forma de organização, observei - não apenas na Herdeiros do Sião, mas também em muitas outras de características semelhantes - que as congregaçôes são formadas por um pastor responsável pela gerência da igreja. Há também os missionários que, embora não tenham o status de pastor, atuam de forma semelhante, inclusive ministrando pregaçôes. Os demais são chamados "obreiros", responsáveis pelas outras funções organizativas. Ao se inserirem oficialmente na igreja, recebem funçôes e orientaçôes sobre a conduta a ser exercida em uma aula doutrinária chamada escola bíblica dominical. Para garantir o cumprimento das "doutrinas", tais condutas são constantemente vigiadas, existindo puniçóes àqueles que, porventura, as violarem. Tais sançóes são tanto mais severas quanto mais altos forem os "cargos" exercidos.

A organização de igrejas pentecostais de pequeno porte como a Herdeiros do Siấo se aproxima da definição sobre comunidades morais, categoria desenvolvida por Carla Mafra em clássica pesquisa de 1999. Analisando as pequenas Assembleias de Deus de localidades periféricas, a autora destaca sobre as comunidades morais, a hierarquia institucional flexível e a forte rede de solidariedade. Sobre tais comunidades:

Por mais que exista uma grande flexibilidade no estabelecimento da relação hierárquica entre as redes [...] e pouca fiscalização e intervenção da hierarquia no «domínio» do pastor presidente (pastor da igreja mãe com cargo vitalício), estas características de uma organização institucional «flexível» são somadas para compor "comunidades morais» localizadas: agregados com fortes redes de solidariedade interna e noção clara das açóes limite, aquelas consentidas e não consentidas pelo coletivo (Mafra, 1999, p. 36). 
"Sou canela de fogo": a Herdeiros do Sião, o reteté e a afinidade ELETIVA COM O ETHOS PERIFÉRICO

Intrigada com as primeiras impressōes dos vivazes rituais e da composição da Herdeiros do Sião, percebi uma obviedade: o campo evangélico (Mafra, 2000) era muito mais diverso do que podia supor (Sant'Ana, 2017). Até então, acreditava que todas as vertentes eram próximas e se reconheciam. Por não perceber a heterogeneidade desse campo, procurei um dos pastores da igreja batista do Morro Conquista para me acudir em minhas dúvidas a respeitos das celebraçóes da Herdeiros do Siáo e de templos vizinhos.

Lembro-me que o pastor dissera com o ar severo: "São os reteté. Pessoas desesperadas que vivem da misericórdia de Deus". Não compreendi de todo a fala do pastor. De fato, até associar a Herdeiros do Sião ao nome reteté foi um trabalho que levou certo tempo. Primeiramente, empreendi intensa pesquisa bibliográfica. $\mathrm{Na}$ literatura socioantropológica, raros sáo os trabalhos que abordam especificamente a nomenclatura reteté de Jeová. Clayton Guerreiro $(2016,2018)$, um dos poucos pesquisadores a abordar nomeadamente o tema, argumenta que o termo é bastante polêmico, mesmo no campo pentecostal. Ainda que sua origem seja desconhecida, o autor aponta três hipóteses difundidas para o surgimento do nome. Na primeira delas, reteté seria uma aliteraçáo ao ritmo das músicas executadas durante os rituais, lembrando o forró (Lopes, 2016). Na segunda hipótese, refere-se à uma "brincadeira" sobre a prosódia da glossolalia ${ }^{6}$, aludindo às palavras aparentemente ininteligíveis, mas marcadas pela repetição silábica proferidas durante os rituais (Guerreiro, 2016, p. 16). Na terceira hipótese, reteté seria uma alusão aos cultos das religióes afro-brasileiras, historicamente anatemizadas entre os protestantes e pentecostais. Polêmico ou não, o termo é conhecido principalmente nas periferias brasileiras e, sobretudo, entre os

5 Informação verbal colhida em fevereiro de 2014.

6 Pela teologia pentecostal, glossolalia é um dos dons do espírito santo, possibilitando ao crente a comunicação verbal com a transcendência (Mariano,1999). 
pentecostais. Sobre a descrição de tal religiosidade, novamente, Guerreiro (2018, p. 125) descreve sua tentativa de síntese focada na análise ritual:

Nos rituais do "reteté", há práticas diversas como profecias, visóes, revelações, curas e línguas estranhas, porém, esses cultos se diferenciam principalmente pelos diversos movimentos corporais executados através de danças, gritos, pulos, quedas, tremedeiras, sapateados, giros, marchas e movimentos circulares com os braços. Essas gesticulaçốes são embaladas pela musicalidade expressa nas cançôes conhecidas como "corinhos de fogo" que, grosso modo, são cânticos curtos e repetitivos, que contam histórias bíblicas ou cotidianas por meio de uma gramática tipicamente pentecostal, em ritmos musicais brasileiros - forró, axé, samba e pagode, ao som de instrumentos diversos, incluindo pandeiros, surdos e atabaques.

Em minhas pesquisas tanto nas relaçóes face a face quanto pela internet, descobri dezenas de hinos e oraçóes que remetiam à expressão. Talvez uma das músicas mais representativas seja a canção composta pela pastora Flordelis:

Eu sou canela de fogo, reteté de Jeová, estou nadando no azeite, não consigo parar [...].

Deus vai entrar na tua vida, vai restaurar o teu lar. Sabe aquela enfermidade, hoje o meu Deus vai curar. Vai libertar o teu filho das drogas e da prisão. Sabe aquele teu marido, vai marchar com o varão. Sabe aquela tua filha que vive na perdição, ela vai virar a líder do grupo de oraçãoo (Flordelis, "Eu sou canela de fogo"). 
Percebe-se que os versos abordam sua forma ritual extática. "Nadando no azeite, năo consigo parar", de fato, é uma forma de descrever o caráter sensorial dos cultos reteté. Também chama atenção a forma em que se estabelece a relação entre a transcendência e a vida cotidiana. O Deus reteté é aquele com poder de se inserir nos problemas de seus fiéis. É capaz de restaurar casamentos, é capaz de tirar os filhos "das drogas e da prisão", dando respostas aos problemas enfrentados por grande parte da populaçáo que vive nas periferias urbanas do Brasil (Novaes, 2006, 2012).

Dessa forma, argumento que reteté seja uma possibilidade de expressar uma especificidade de cerimônias de maravilhamento e êxtase pelo espírito (Mafra, 1999, p. 35). A expressividade corporal da dança giratória seria um dos marcadores e fator central do ritual.

Contudo, e isso deve ser dito, a maioria das pessoas que identifico nesse trabalho como associadas ao reteté náo gosta do termo. Acreditam que é uma forma de desmerecimento da religiosidade. Perguntei a um dos integrantes da Herdeiros do Siáo se considerava a congregaçáo como reteté": "isso [reteté] é coisa maligna. Somos uma igreja viva... Muita gente náo entende e fala coisas que não sabe".

Nessa disputa por legitimidade, percebe-se que a religiosidade aqui em questâo é uma categoria de acusação, que, para Becker (2008, p. 27), envolve relaçôes de poder e hierarquia, estabelecendo fronteiras classificatórias entre o que acusa e o acusado. Gilberto Velho (2008, p. 66) vai destacar o caráter instável e circunstancial do processo de acusação, possibilitando a negociação sobre a forma como se estabelecem os termos. Dessa forma, a acusação sobre os reteté se estabelece principalmente entre os protestantes históricos e/ou calvinistas, delimitando uma fronteira entre uma religiosidade supostamente racional e teologicamente correta, em direta acusaçáo à suposta expressáo "herética" e "enganosa" dos reteté (Silveira, 2015, p. 38).

Sobre a acusaçáo relacionada aos seguidores dessa religiosidade, argumento que ao negarem o estigma de reteté, os integrantes estigmatizados operam a partir da "condição de desacreditado", tal como explica Goffman (1988, p. 14). Assumindo uma capa defensiva, aqueles estigmatizados 
respondem de distintas formas a acusação. Guerreiro (2016, p. 202-204) traz um interessante exemplo. Destaca que uma das principais acusaçôes a se recair sobre os adeptos da vertente religiosa em discussão neste artigo é a categoria "meninice"; ou seja, eles seriam poucos sérios e "imaturos na fé" (Guerreiro, 2016, p. 202-204). Por outro lado, entre os reteté, tal acusação é rebatida ao destacarem que a suposta imaturidade espiritual seria contraposta pela "inocência infantil":

Assim, se para os críticos do reteté, a meninice indicaria falta de seriedade dos que os praticam, os que têm tais práticas justificam suas performances, afirmando que são as práticas de certos pecados que indicariam a suposta falta de seriedade. Assim, de acordo com eles, "não adulterar" (forma como os pentecostais se referem à prática do adultério) é que deveria ser considerado algo a se preocupar (Guerreiro, 2016, p. 204).

Contrapostas, as falas do pastor batista apresentada no início do item e daqueles que se defendem da acusação sobre o reteté colocam em perspectiva em complexo processo de busca por legitimidade dentro do campo evangélico e mesmo no campo pentecostal. Nessa disputa, as acusações (Goffman, 1988) se relacionam colocando em evidência a heterogenia do campo. Ao acusar os reteté de serem "desesperados", o pastor batista explicita uma disputa importante entre protestantes não pentecostais e entre os pentecostais. Nesse campo, se os protestantes mais tradicionais acusam os pentecostais de heréticos, ignorantes, em uma associação à condição de pobreza (Silveira, 2015), em sentido amplo, os pentecostais acusam os protestantes tradicionais de serem "frios", cultuadores de um uma expressão estática do divino. Apresento depoimento de uma jovem pentecostal da Herdeiros do Siâo sobre a igreja presbiteriana, considerada protestante histórica: "Eles servem ao Jesus que ficou lá, pregado na cruz. O Deus que eu sirvo é vivo, ele circula pelo poder do espírito santo" (entrevista com Marta, 24 de janeiro de 2014).

Mesmo no campo pentecostal, no qual o culto ao espírito santo é um denominador comum, as disputas são significativas. Durante a estada em

Debates do NER, Porto Alegre, ANo i9, N. 36, P. 267-305, Ago./Dez. 20 i 9 
São Pedro, percebi que alguns pentecostais acusam as igrejas de grande porte, entre as quais a Igreja Universal do Reino de Deus (IURD), de serem menos "sinceras' ou se" preocuparem com dinheiro". A auxiliar de serviço gerais Mara ${ }^{7}$ ratifica tal posição: "As igrejas de bairro são mais sinceras. Não pensam tanto em dinheiro tipo as igrejas grandes. Têm menos falsos profetas, que não estão preocupados com o reino de Deus”.

Reitero, porém, ao estabelecer o reteté como categoria de acusação, que não é minha intenção esgotar o termo e tampouco definir e classificar expressóes religiosas como pertencentes ou não ao escopo semântico da categoria (Bispo, 2010, p. 14; Silveira, 2015, p. 47). Antes disso, a intenção é atentar para as disputas envolvendo o termo, explicitando as rupturas, apreensões, tensões e instabilidades que rodeiam tal expressão. Assim, a associação dos rituais reteté e das pequenas igrejas pentecostais não cabe em classificaçóes automáticas. Nesse sentido, as observações de Giumbelli (2001) ganham importância por contestarem interpretaçôes que versem sobre um sentido de pureza nas classificaçóes sobre o campo evangélico:

Todas as críticas dirigidas ao paradigma da "pureza nagô", elaboradas por uma geração inteira de pesquisadores [...], deveriam servir de alerta para que procedimento análogo não fosse aplicado a um outro segmento do campo religioso e para que privilegiássemos outras formas de considerar as inegáveis transformaçóes que ocorrem entre os evangélicos e as especificidades que acompanham sua expansão no Brasil. Mas, além dessa, outras razões existem para desaconselhar a direção seguida pelas formulações dominantes em termos de terminologias e classificaçóes do protestantismo. É preciso lembrar que o pentecostalismo não é interesse exclusivo de estudiosos. (Giumbelli, 2001, p. 111-112).

Nesse sentido, a diversidade e heterogeneidade das igrejas pentecostais de pequeno porte e a imprecisão classificatória dos rituais reteté dão provas do dinamismo e complexidade do campo pentecostal e evangélico (Mafra,

${ }^{7}$ Nome fictício escolhido pela interlocutora. Depoimento colhido em janeiro de 2018. 
2000). Dessa feita, denominaçôes como a Herdeiros do Sião não podem ser associadas completamente à tipologia de Mariano (1999) e Freston (1994), revelando uma pentecostalidade (Duarte, 2005, p.165) "impura” e rica em intersecçôes e circulação fronteiriças (Coleman, 2018). Marcadas pela relacionalidade própria das camadas populares (Duarte, 1986, 2005), figuram-se como expressôes do "fundo de crença dos grupos populares" (Fonseca, 1991, p. 131, tradução minha), no qual a experiência pentecostal, longe de minar a experiência da diversidade simbólica religiosa, acrescenta a ela novos elementos (Fonseca, 1991, p. 131).

Dessa forma, as disputas por legitimidade dentro do campo pentecostal remetem explicitamente às assimetrias dentro do próprio campo, revelando relaçôes de poder que se refletem em diferenças de visibilidade no espaço público. Raquel Sant'Ana (2014) destaca que, a partir das assimetrias, nas quais alguns grupos são mais visíveis em detrimentos de outros, é possível estabelecer relaçôes metonímicas, em que determinados grupos evangélicos passam a ser imaginados (Asad, 2003) e nomeados como representantes da totalidade do campo evangélico (Sant'Ana, 2014).

Nesse mesmo sentido, podemos pensar que a configuração dos "evangélicos" enquanto campo discursivo não é livre de assimetrias. Ao contrário, se dá a partir da produção de metonímias, apresentando certos grupos e lideranças como a totalidade dos "evangélicos" a partir das posições privilegiadas que ocupam em relação aos recursos da indústria cultural e da política parlamentar. [...] Assim, tem sido possível pensar em "evangélicos" a partir do cruzamento entre uma produçâo parlamentar e midiática, revelando disputas e projetos que se tornam metonímia dos $22 \%$ dos brasileiros apontados pelo censo, ele próprio objeto de promoção midiática da existência desse segmento (Sant’Ana, 2014, p. 213).

Argumento, em consonância, que a forma de organização centrada em pequenas comunidades religiosas localizadas nas periferias contribui para a relativa invisibilidade de tais manifestaçóes como possibilidade imaginativa (Asad, 2003) da composição dos evangélicos como campo discursivo 
na cena pública. Em outras palavras, aduzo que a própria organização em pequenas comunidades, sem a formação de lideranças para além das próprias denominações e, principalmente, a associação ao cotidiano dos universos periféricos - estes, também estigmatizados e invisibilizados (Oosterbaan, 2008; Machado, 2005) - contribuem para a relativa invisibilidade das manifestaçóes reteté das pequenas comunidades religiosas no espaço público mais amplo.

\section{A Herdeiros do Sião e a periferia}

Nessa esteira, a diversidade de igrejas pentecostais com características próximas à Herdeiros do Sião em um bairro como São Pedro suscita o questionamento sobre a própria amplitude da relação entre as pequenas denominaçôes pentecostais e a vivência nas periferias em um sentido mais geral (Fonseca, 1991; Machado, 2018; Vital da Cunha, 2015).

É plausível recorrer aos números. De acordo com o Censo Religioso realizado em 2010 (IBGE, 2010), a maior denominação evangélica do Brasil é a Assembleia de Deus ${ }^{8}$, com cerca de 29\% de adeptos. As igrejas protestantes clássicas - contando com os batistas, luteranos, metodistas e presbiterianos -, não chegam a $10 \%$. As demais denominaçóes pentecostais são as de grande porte - entre as quais, a Igreja Universal do Reino de Deus, a Adventista, a do Evangelho Quadrangular e a Deus é Amor -, que somam pouco mais de $10 \%$. Interessante notar que a categoria "outras", utilizada pelo Censo para se referir a igrejas de pouca expressão numérica, chega a $34 \%$. Assim, é possível aferir que boa parte dessas "outras" igrejas evangélicas guardem semelhanças às pequenas pentecostais, como a Herdeiros do Sião.

Clara Mafra (2011, p. 136) chega a falar em um cinturão pentecostal nas periferias urbanas. Diz a autora que há uma relação de proporcionalidade. Quanto mais afastada dos centros, mais pentecostal e menos católica é a região.

${ }^{8}$ A relação entre os reteté e a Assembleia de Deus será melhor analisada em itens posteriores. 
Boa parte das metrópoles latino-americanas entrou no século XXI com uma configuração urbana peculiar, o chamado "cinturão pentecostal": em torno de um núcleo urbano antigo, com infraestrutura consolidada e uma maioria de residentes católicos, formou-se um cinturão periférico, de colonização recente, infraestrutura precária e alta presença de pentecostais (Mafra, 2011, p. 136).

Evidentemente não há como identificar todas as pequenas igrejas pentecostais que povoam as periferias brasileiras à ritualística reteté. Insistir em tal premissa seria recair em uma redução classificatória e conceitual como já foi explanado aqui (Giumbelli, 2001, p. 111-112).

Argumento, contudo, analisando o caso da Herdeiro dos Sião, dado seu pequeno porte possibilitando a formação de hierarquias mais horizontalizadas e a organização em comunidade moral tradicionalmente focada em cerimônias de maravilhamento e êxtase pelo espírito como observado por Mafra (1999, p. 35), que há uma associação entre denominaçóes com elementos ritualísticos que se aproximam da categoria que neste texto se denomina como reteté ao universo das periferias brasileiras. Clayton Guerreiro (2018, p. 123) também percebeu tal associação:

[...] analiso conflitos protagonizados por fiéis pentecostais, supondo que são evidenciados, encenados e atualizados nos rituais pentecostais conhecidos como "reteté". Esses rituais ocorrem principalmente em pequenas igrejas da periferia das grandes cidades brasileiras, onde ocorrem vigílias pentecostais.

Silveira (2015, p. 38) destaca a relação do termo reteté às camadas populares:

As igrejas pentecostais re-te-té [...] podem ser identificadas por um grupo de características que marcou o surgimento do pentecostalismo no início do século XX nos EUA e no Brasil: periferia, pobres, negritude, mulheres e intensa presença do corpo (danças, giros, música batida, espasmos, rodopios e desmaios). Essas características não são propriamente novidades mas nos últimos dez anos [...] essa faceta do fenômeno ficou evidente e, com isso, as categorias de acusação foram acionadas.

Debates do NER, Porto Alegre, ANo i9, N. 36, P. 267-305, Ago./Dez. 20 i 9 
Dessa forma, se proponho uma associação entre a religiosidade reteté da Herdeiros do Sião à vivência periférica (Novaes, 2012, p. 195), necessária se faz a delimitação sobre a conceituação de periferia utilizada aqui. Tema vastamente estudado nas Ciências Sociais (Le Goff, 1998; Blumenfeld, 1972; Sellier, 1992; Santos, 1981; Kowarick, 2000; Sposito, 1993), periferia, no recorte proposto, é abordada para além de uma referência meramente espacial, ou mesmo de uma leitura, na qual o contexto periférico é visto unicamente como espaço de carência e de precariedade de serviços públicos. Assim, a abordagem proposta prevê uma ampliação do conceito (Dayrell, 2007, p. 1112; Novaes, 2006, p. 190), destacando que, embora tais fatores sejam levados em conta, periferia se refere a um ethos específico marcado, também, por relaçóes afetivas de sociabilidade. Cito as precisas palavras de Dayrell (2007, p. 1112):

Periferia não se reduz a um espaço de carência de equipamentos públicos básicos ou mesmo da violência, ambos reais. Muito menos aparece apenas como o espaço funcional de residência, mas surge como um lugar de interaçóes afetivas e simbólicas, carregado de sentidos. Pode-se ver isso no sentido que atribuem à rua, às praças, aos bares da esquina, que se tornam, como vimos anteriormente, o lugar privilegiado da sociabilidade ou, mesmo, o palco para a expressão da cultura que elaboram, numa reinvenção do espaço.

Neste sentido, entendendo periferia como lócus de interaçôes específicas, advogo que os ruidosos, sensoriais e extáticos rituais das pequenas igrejas como a Herdeiros do Sião, são expressóes privilegiadas dos contextos das periferias urbanas; onde tais igrejas, na significativa maioria dos casos, estão inseridas.

\section{O RETETÉ E AS PERIFERIAS: AFINIDADE ELETIVA}

Desse modo, é possível falar em uma relação de afinidade eletiva (Weber, 2004) entre as pequenas igrejas reteté como a Herdeiros do Sião e os contextos periféricos. Contudo, é preciso destacar que ao utilizar o termo weberiano, 
saliento, em primeiro lugar um movimento mais complexo do que a simples relação causal. Dessa forma, explicita-se uma obviedade: nem todas as igrejas com características reteté estão localizadas na periferia, assim como nem todas as igrejas situadas na periferia apresentam caraterísticas que remetem ao reteté. No entanto, ao retomar o sentido weberiano dado à expressão afinidade eletiva, busco destacar uma relação de analogia, um fluxo de convergências da ritualística reteté vivenciada em muitas das pequenas igrejas pentecostais tão fartamente presentes na experiência periférica.

Citado três vezes em $A$ ética protestante e o espirito do capitalismo (Löwy, 2011, p. 131), com "afinidade eletiva", Weber (2004) analisava a relação de reciprocidade entre o protestantismo enquanto movimento religioso e o desenvolvimento de uma ética específica sob o capitalismo:

Em face da enorme barafunda de influxos recíprocos entre as bases materiais, as formas de organização social e política e o conteúdo espiritual das épocas culturais da Reforma, procederemos tão-só de modo a examinar de perto se, e em quais pontos, podemos reconhecer determinadas "afinidades eletivas" entre certas formas da fé religiosas e formas da ética profissional. Por esse meio e de uma vez só serão elucidados, na medida do possível, o modo e a direção geral do efeito que, em virtude de tais afinidades eletivas, o movimento religioso exerceu sobre o desenvolvimento da cultura material (Weber, 2004, p. 81).

Michael Löwy (2011) sublinha o caráter eminentemente dinâmico da relação de afinidade eletiva. Com a expressão, Weber destacava uma relação necessariamente ágil, inerentemente simbiótica, ativa e continuamente reforçada mutuamente.

Afinidade eletiva [...] contém o elemento da seleção, da escolha ativa, da atração recíproca. [...] Para Weber, que é antes de tudo um sociólogo da ação social, essa diferença entre a simples "afinidade" e a afinidade eletiva, entre uma analogia formal e uma relação ativa, não poderia passar desapercebida [...] opomos, então, a seguinte definição, partindo do uso weberiano do termo: afinidade eletiva é o processo pelo qual duas formas culturais - religiosas, 
intelectuais, políticas ou econômicas - entram, a partir de determinadas analogias significativas, parentescos íntimos ou afinidades de sentidos, em uma relação de atração e influência recíprocas, escolha mútua, convergência ativa e reforço mútuo (Löwy, 2011, p. 138-139).

Dessa forma, tendo em consideração o caráter retroatrativo entre o ethos periférico e a experiência de uma pequena comunidade moral de ritualística reteté como a Herdeiros do Sião, a afinidade eletiva se manifesta em uma relação de complementaridade, materializada na significativa variedade de igrejas com características semelhantes localizadas nas periferias, tal como observado no campo. As pequenas, ruidosas e numerosas igrejas pentecostais em suas generalidades e em suas especificidades, compóem de forma privilegiada os contextos das periferias, numa relação dinâmica e intrínseca com a experiência periférica.

Cláudia Fonseca (1991), em etnografia sobre vivência religiosa na Vila José, um bairro popular de Porto Alegre (RS), percebeu a relação entre os diferentes grupos religiosos e a experiência cotidiana dos moradores. Para a autora, as interaçóes ocorrem tanto em um nível vertical, forjada no interior das denominações religiosas, como em nível horizontal, a partir das relaçōes entre vizinhos.

Em consonância, ampliando as reflexôes sobre afinidade eletiva entre comunidades pentecostais com a vizinhança nos contextos em que se inserem é possível analisar as colocações de Simon Coleman (2006). O autor, ao refletir sobre ética e ação, destaca que as expressóes pentecostais se estabelecem necessariamente em uma condição de abertura de suas fronteiras. A relação, sempre tensionada e dinâmica, com o contexto fora das comunidades pentecostais é um fator que conforma essas próprias comunidades, numa interação na qual as fronteiras são constantemente acionadas, num movimento de permanente construção.

Um ponto similar, e muitas vezes subestimado, é que as fronteiras através dos quais os Pentecostais atuam não estão simplesmente "por aî", expressando de alguma maneira as diferenças essenciais entre as visóes Pentecostal e local sobre o mundo. Elas são constantemente construídas e reconstruídas pelos fiéis, 
embora muitos autores pareçam pensar que o principal motivo para examinar a atividade pentecostal é pela sua habilidade de converter não-cristãos às suas visóes de mundo. Prefiro reforçar que é igualmente importante examinar outra dimensão da fronteira: as formas pelas quais o Pentecostalismo em si se reconstrói através da afirmação de sua necessidade de trabalhar nas fronteiras que envolvem tanto os fiéis, quanto os não fiéis [...] Tais prestaçôes de conta são certamente uma forma de auto-objetivação, e a audiência pode ser tanto o Eu, como um suposto Outro (Coleman, 2006, p. 288).

Assim, especificando a relação de afinidade eletiva e o movimento de construção fronteiriça entre a Herdeiros do Sião e o contexto de São Pedro e do Morro Conquista, observei que além da evidente associação aos valores hierárquicos (Dumont, 1985; Duarte, 1986; 2005) manifesto nas relaçóes de vizinhança e das redes de parentesco, o ethos periférico se estabelece a partir de uma paisagem sonora (Schafer, 1997) bastante específica9 ${ }^{9}$ Em São Pedro e o Morro Conquista, a intensa circulação de pessoas nos becos e vielas é embalada pelos sons das conversas, das músicas de funk, do pagode, dos hinos evangélicos, que compóem uma confluência sonora marcada por referências locais e globais (Pereira, 2018). Na junção sonora do Morro Conquista, igrejas pentecostais como a Herdeiros do Sião disputam a política da presença (Oosterbaan, 2008) por meio dos sons que produzem. Assim, a presença desses templos religiosos de pequeno porte é percebida pela exaltação de seus louvores e hinos, transmitidos à significativa distância. Muitas vezes presenciei "rodas" de jovens que não eram oficialmente pentecostais conversarem alguns portando roupas associadas ao funk nas calçadas em frente as igrejas (Pereira, 2018). Além disso, observando as recomendaçóes de Forsey (2010) sobre a escuta etnográfica parecia se estabelecer na região, uma certa rotina sonora baseada nos cultos. Depois de um tempo morando em Conquista, já consegui distinguir quais cânticos e oraçôes pertenciam a algumas das diversas igrejas vizinhas à minha casa.

9 “[...] o ambiente sonoro. Tecnicamente, qualquer porção do ambiente sonoro vista como um campo de estudos" (Schafer, 1997, p. 366).

Debates do NER, Porto Alegre, Ano i9, N. 36, P. 267-305, Ago./Dez. 20 i 9 
“DeIXa o MENINO RODAR": O SOBRENATURAL, O FOGO E OS CORINHOS

Diante da pluralidade de igrejas pentecostais de pequeno porte presentes em Conquista, tentei entender alguns dos pontos distintivos observados em tais denominaçóes, tendo como cerne a experiência na Herdeiros do Sião. Pondero, contudo, que não é intenção promover uma tipologia. Antes disso, trago alguns pontos de reflexão que, acredito, possam trazer luzes sobre a singularidade da forma de religiosidade aqui abordada em sua relação com o ethos periférico a partir de uma relação de afinidade eletiva e construção fronteiriças. Talvez o mais expressivo desses pontos seja a associação explícita dos rituais pentecostais com a dimensão sobrenatural. O termo, aliás, está presente tanto nos cultos quanto no cotidiano. Para iniciar a reflexão sobre como essa dimensão sobrenatural é experienciada, cito algumas músicas associadas diretamente a ele:

Eu sou pentecostal,

fui gerado no fogo,

eu fui nascido no fogo,

o meu ambiente é o sobrenatural.

Sou batizado com fogo,

sou renovado com fogo.

Eu sou curado no fogo,

meu ambiente é o sobrenatural

(Flordelis, "Eu sou pentecostal”, grifos nossos).

Os versos apresentados acima trazem uma questão importante a respeito da pentecostalidade produzida em comunidades morais (Mafra, 1999) como a igreja Herdeiros do Sião. Percebe-se que a dimensão sobrenatural é representada pelo elemento "fogo". Presente na narrativa bíblica sobre o surgimento do espírito santo, a associação com o elemento fogo pode ser percebida como 
a sensação sinestésica do contato com o espírito santo. Expressões como "é puro fogo" e "o fogo desceu" são ditas repetidas vezes nos cultos ${ }^{10}$.

Atestando a importância do elemento fogo durante a estada em Conquista, percebi que os integrantes das igrejas pentecostais são muitas vezes chamados de "canelas de fogo" ou de "sapatos de fogo". O próprio contato com o espírito é chamado de "batismo pelo fogo". Assim, em um culto reteté, principalmente no momento do avivamento, há a junção de dois elementos: o fogo e o espírito sobrenatural. Na igreja Herdeiros do Sião, como em tantas outras de caráter semelhante observadas, no momento do avivamento, no qual ocorrem as manifestaçôes do espírito santo, os integrantes - em geral pobres, negras, mulheres - assumem-se como guerreiros numa batalha, na qual têm o próprio Deus, travestido como espírito santo, como aliado. Cito música bastante executada nos rituais:

Ele é um anjo de fogo,

no seu pé tem fogo.

Na sua mão tem fogo,

no cabelo tem fogo,

no seu andar tem fogo,

ele caminha no fogo aqui neste lugar.

Labareda de fogo,

fogo, fogo, fogo.

${ }^{10}$ Não apenas nas pequenas igrejas pentecostais o fogo é elemento fundante; observa-se que a associação com o fogo diz respeito à própria narrativa de origem do pentecostalismo. De acordo com os pentecostais, a explicação sobre o espírito santo encontra-se em um dos livros da Bíblia, denominado Ato dos Apóstolos. Lendo a narrativa, percebe-se que Jesus Cristo, após ascender aos céus, teria enviado aos seus discípulos uma força em forma de línguas de fogo. $\mathrm{O}$ contato com tais manifestaçôes teria resultado em exaltação física, e a partir daquele mana, os discípulos se puseram a falar todas as línguas do mundo. Essa força em forma de fogo era o espírito santo Este, em resumo, é o mito inicial dos pentecostais. É possível dizer que o culto e a crença na atualidade do espírito santo são os denominadores comuns entre pentecostais, entre os quais estão inseridos os reteté.

Debates do NER, Porto Alegre, ANo i9, N. 36, P. 267-305, Ago./Dez. 20 i 9 
Sinta a glória de fogo,

fogo, fogo, fogo.

Levante a mão e receba fogo,

fogo, fogo, fogo do altar.

Labareda de fogo,

fogo, fogo, fogo.

Sinta a glória de fogo,

fogo, fogo, fogo.

(Fogo no Pé, "Labareda de fogo", grifos nossos) $)^{11}$

Outro ponto que destaco sobre a pentecostalidade exercida na Herdeiros do Sião são os cultos de batalha espiritual. Na igreja, observei que as celebrações de batalha espiritual são mais sensoriais e mesmo menos dependente do dirigente litúrgico do que os cultos observados na Igreja Universal, onde a batalha seria, segundo Mariano (2003, p. 25) "hipertrofiada”. De fato, não presenciei no tempo de campo na Herdeiros do Sião rituais de exorcismo como os observados nas IURDs. ${ }^{12}$ Contudo, destaco que observei que, mesmo o exorcismo não se conformando como prática corrente nos rituais reteté da Herdeiros dos Sião, a batalha espiritual se apresenta e assume um conteúdo extremamente beligerante e igualmente hiperbolizado. Palavras como "batalha", "peleja”, "guerra”, "marchar” são comuns em diálogos travados nos rituais e na vida cotidiana. Apresento emblemático hino, "Batalha travada", bastante executado durante os rituais observados. $\mathrm{Na}$ letra, a repetição das palavras "batalha", "peleja e "valente" dão o tom:

Batalha travada é nessa Terra.

Eu entrei nessa peleja foi pra pelejar.

${ }^{11}$ LABAREDA de fogo. [S. l.: s. n.] , 2015. 1 vídeo (ca. 5 min). Publicado pelo canal Claudete Santos. Disponível em: https://www.youtube.com/watch?v=kp_eMWDagXo. Acesso em: 2 set. 2019.

12 A menor ênfase aos rituais de exorcismo em pequenas comunidades morais foi observada desde Clara Mafra (1999). 
Eu entrei nesta guerra foi pra guerrear, eu entrei nessa peleja foi pra pelejar, nessa terra.

Ele é valente na batalha (4x).

A batalha vai começar,

a batalha vai começar.

Esta terra é de conquista

e o mais valente conosco está.

(Ednaldo do Rio, "Batalha travada")

Um ponto significativo: as músicas entoadas durante o momento de avivamento têm papel importante para a experiência extática. Existe uma categoria especial de músicas relacionadas à experiência de transe. Tais músicas são chamadas de "corinhos de fogo".

Em minhas observaçóes, percebi que há uma rede de cantores e compositores de corinhos. Alguns inseridos no mercado gospel mais amplo e profissionalizado, como o grupo Fogo no Pé e as cantoras Damares e Cassiane. Mas, além disso, percebo uma dinâmica entre as próprias igrejas reteté. Alguns cantores e compositores costumam circular entre as denominações apresentando suas músicas. Presenciei um desses cantores em visita à Herdeiros do Sião, em 2014. Durante o culto, cantou uma música, um forró em ritmo acelerado.

Além das redes entre as igrejas, a internet, em especial a plataforma de vídeos YouTube, parece ser terreno propício para a divulgação dos corinhos de fogo. Uma pesquisa rápida é suficiente para perceber a diversidade de artistas que se dedicam aos corinhos, e os temas são diversos (Albuquerque Jr., 2014). Há os de caráter pedagógico, como "Varoa do reteté"13, que trata do papel feminino nas comunidades religiosas; ou "Crente disfarçado", sobre

${ }^{13}$ VAROA do reteté. [S. l.: s. n.], 2017. 1 vídeo (ca. 4 min). Publicado pelo canal Muro de Fogo Oficial. Disponível em: https://www.youtube.com/watch?v=cuHYZPvK7PM. Acesso em: 2 set. 2019.

Debates do NER, Porto Alegre, Ano i9, N. 36, P. 267-305, Ago./Dez. 20 i9 
a hipocrisia nas relaçôes dentro da igreja: "diz que é do manto, diz que é mulher de oração, mas usa a língua pra falar mal dos irmãos" ${ }^{14}$.

Há também os corinhos em críticas diretas a outras denominaçôes religiosas. Deste tema, cito "Macumba não mata crente", sobre as religióes de matrizes africanas, em especial à umbanda: "Mas porque eu sou protegida, revestida de poder. Podem até fazer macumba, mas quem fez é quem vai morrer" ${ }^{15}$. Há ainda críticas ao catolicismo. Em "Deixa Maria por Jesus", o corinho começa com a introdução de "Ave Maria", clássico do francês Charles Gounod. Após a introdução, o ritmo de forró irrompe: "Deixa Maria por Jesus. Quem morreu na cruz pra me salvar, não foi Maria, foi Jesus"16, 17 . Contudo, apesar da diversidade de temas, a maioria das músicas possui um tom beligerante e bélico, o que é de extrema importância litúrgica para os ritos reteté.

Devo dizer, porém, que os corinhos não são as únicas categorias de música executadas nos rituais. Além deles, existem os hinos de louvor, que geralmente possuem um conjunto melódico mais diverso e menos exaltado, mais próximo ao gospel religioso norte-americano. Contudo, liturgicamente, os corinhos de fogo são geralmente executados como uma espécie de "evocação" ao espírito santo e, geralmente, são os corinhos as músicas ouvidas durante o momento do avivamento. Argumento que a própria estrutura melódica é geralmente composta por um padráo rítmico. De acordo com Arthur Costa Lopes (2016, p. 615), a estrutura costuma ser composta "por duas colcheias e uma semínima

${ }^{14}$ CRENTE disfarçado. [S. l.: s. n.], 2018. 1 vídeo (ca. 7 min). Publicado pelo canal Kleber Corrêa. Disponível em: https://www.youtube.com/watch?v=KZk1xy8ow8I. Acesso em: 2 set. 2019.

${ }^{15}$ MACUMBA não mata crente. [S. l.: s. n.], 2017. 1 vídeo (ca. 6 min). Publicado pelo canal Grupo de Louvor Geração Peniel. Disponível em: https://www.youtube.com/ watch?v=KFIDitNHt5A. Acesso em: 2 set. 2019.

${ }^{16}$ DEIXA Maria por Jesus. [S. l.: s. n.], 2016. 1 vídeo (ca. 5 min). Publicado pelo canal Delcidio Rodrigues: Disponível em: https://www.youtube.com/watch?v=fW_qxoG43QI. Acesso em: 2 set. 2019.

${ }^{17}$ Em alguns corinhos, percebi um tom jocoso. 
(compasso binário, na qual a semínima é a referência)" (Lopes, 2016, p. 615), o que, para o estudioso, remetem ao ritmo forró. Acredito que o forró executado pelos corinhos reflita o tom de euforia das cerimônias de avivamento. Além disso, sua composição poética é marcada pelas várias e criativas rimas, conferindo musicalidade às letras. "Divisa de fogo", do grupo Fogo no Pé:

Divisa de fogo, varão de guerra.

Ele desceu na Terra.

Ele chegou pra guerrear (4x).

Foi no quartel general, de Jeová,

você tem que aprender, você tem que adorar.

E uma bola de fogo aqui descerá,

se você tem olhos ungidos,

pode contemplar.

Mas desceu um Varão Resplandecente lá da glória

(Fogo no Pé, "Divisa de fogo") ${ }^{18}$

Composto por uma introdução e poucos acordes de harmonização, percebe-se pelos grifos na citação a preocupação com as rimas ${ }^{19}$. Para Gilbert Rouget (1980, p. 180), os significantes musicais têm uma dimensão denotativa e afetivo-emotiva, que remeteriam a estados emocionais como a alegria, a tristeza, a raiva (Rouget, 1980, p. 150). Todas essas dimensões, que são construídas culturalmente, podem possibilitar o estado de transe (Aubrée, 1996). Assim, acredito que, como a maioria dos corinhos de fogo, a música "Divisa de fogo", com suas repetiçóes harmônicas, conduza a uma dimensão afetiva que remete a um caráter beligerante conhecido e reconhecido nos rituais reteté. Destaco que tal caráter beligerante não se estabelece apenas pela melodia,

${ }^{18}$ DIVISA de fogo. [S. l.: s. n.], 2013. 1 vídeo (ca. 3 min). Publicado pelo canal Marcos Paulo Ferreira da Silva. Disponível em: https:/www.youtube.com/watch?v=5zZ4rvAazYE. Acesso em: 2 set. 2019.

${ }^{19}$ Agradeço as valiosíssimas contribuiçôes do cantor lírico Evandro Santana e do pianista Saulo Araújo.

Debates do NER, Porto Alegre, Ano i9, N. 36, P. 267-305, Ago./Dez. 20 i9 
mas também pelas letras. "Varão de guerra", "guerrear", "quartel general", "vitória” são expressôes presentes na letra de "Divisa de fogo". São expressões conhecidas pelo grupo. Lembro-me que nos cultos da Herdeiros do Sião e de outras igrejas reteté, quando corinhos expressivos como o "Divisa de fogo" eram executados, havia uma evidente mudança de tom. As palmas ficavam mais fortes; os cânticos, mais intensos; os gritos de aleluia ganhavam mais força. Assim, como um misto de forró e de grito de guerra, de emblema e de catarse, o corinho de fogo se estabelece como possibilitador de uma experiência religiosa coletiva associada à experiência do contato pelo espírito santo. Uma experiência que, segundo os interlocutores, é afetiva e sinestésica, remetendo a um caráter revigorante de "poder", "renovação", "fogo", "vitória" e "batalha".

Além dos corinhos de fogo, a performance corporal nos cultos também reflete a associação com o sobrenatural. Sob o contato com o espírito santo, os fiéis parecem reproduzir um padrão corporal de uma dança rodada. Como já mencionado, os integrantes, aparentando transe, costumam "rodar", como um balé giratório. Alguns fiéis usam a expressão "manto" para se referirem a essa performance. Novamente, cito um corinho de fogo que aborda a tal dança rodada.

Eu posso ser crente menino, mas não adultero, eu posso ser crente menino, mas eu não me vendo, eu posso ser crente menino, mas eu sei adorar, então deixa o menino rodar.

Deixa o menino rodar. $(4 \mathrm{x})$

Que que tem, que que tem se eu rodo assim?

Que que tem, que que tem se eu dou lugar assim?

Que que tem se eu adoro assim?

É melhor pular aqui do que lá na Sapucaí

(Ministério Ardendo em Fogo, “Crente menino") ${ }^{20}$

${ }^{20}$ CRENTE menino. [S. l.: s. n.], 2016. 1 vídeo (ca. 3 min). Publicado pelo canal Celebrai Music. Disponível em: https://www.youtube.com/watch?v=-2n_LjSoTVg. Acesso em: 2 set. 2019. 
Quando abordamos a ligação com o sobrenatural, fatalmente abordamos os conceitos de transe, experiência extática e possessão, que são temas ancestrais na Antropologia (Turner, 1974; Evans-Pritchard, 2005) - desde os estudos do xamanismo, que vão desde Boas, passando por Lévi-Strauss, até chegar a autores como Langdon (1996) e Lewis (1971). No Brasil, os estudos sobre transe e possessão, na maioria das vezes, estiveram ligados às religióes de matriz africana (Maggie, 1975; Goldman, 1985; Birman, 1996).

Nesse sentido, presenciei o uso de termos como "manto do espírito", que seria a forma como o espírito santo se manifesta sobre o fiel. Alguns integrantes da Herdeiros do Sião falam que a sensação é como se o espírito os "cobrisse" tal qual um manto. Outro termo é a "revelação", uma espécie de profecia, em que o contato com o espírito santo "revela" algum fato sobre uma pessoa ou situação. Também há a categoria "mistério", que é usada para designar fatos sobrenaturais e sem explicação. O mistério, contudo, é sempre ligado a Deus e nunca ao diabo. Aqueles agraciados pelos dons da revelação, aqueles que têm contato próximo aos mistérios, são considerados profetas: Percebo que os profetas têm grande prestígio nas relaçóes travadas dentro templo. Considerados os mais ungidos, geralmente exercem funçôes de liderança (Pereira, 2018).

Durante os cultos, a revelação profética costuma acontecer durante o avivamento. As oraçóes são irrompidas com expressōes utilizadas pelos profetas bíblicos: "Eis que te digo!", "Assim diz o Senhor!", "Deus manda dizer!" são algumas das expressōes que costumam proferir aqueles agraciados pelo dom da revelaçáo. É a senha para o momento de "entregar a profecia" ou "entregar o mistério". O profeta revela a profecia individualmente. Cada um dos participantes dos cultos pode ser escolhido para uma revelaçáo. As revelaçôes podem dizer respeito a supostas "feitiçarias" ou "macumbarias"; a pecados cometidos por algum fiel; a um "livramento" recebido. Em uma comparação com os rituais da Herdeiros do Sião e de outras igrejas de pequeno porte presentes nas periferias, nas quais a figura da profecia é um valor estimado, observa-se em denominaçôes de maior porte com estrutura mais hierarquizada, como a IURD, que a revelação não é apenas desesti- 
mulada, mas combatida ${ }^{21}$. Na página eletrônica da IURD, por exemplo, o dirigente Edir Macedo condena textualmente a prática da profecia:

Nada tem sido tão devastador nas igrejas como a ignorância com respeito às profecias. Da mesma forma como Satanás tem usado a falsidade de línguas estranhas também tem se aproveitado da falta de discernimento espiritual com respeito às profecias. E o pior é que muita gente escolada também tem se rendido às farsas das "profetas" que, diga-se de passagem, são mulheres mal casadas ou frustradas sentimentalmente. ${ }^{22}$

Há que se dizer, contudo, que existe certa desconfiança para com alguns profetas. Ouvi integrantes da Herdeiros do Sião se dizerem desconfiados sobre a veracidade das revelaçôes de alguns "irmãos"; percebi outros dizerem que os dons proféticos de terceiros eram advindos do "diabo". Contudo, reitero que aqueles profetas considerados realmente ungidos possuem grande status na comunidade religiosa.

Percebi entre aqueles considerados profetas uma conotação de orgulho e poder. Em outro corinho de fogo, chamado de "Não toque no ungido", percebe-se uma postura orgulhosa do crente em sua relação com a transcendência. Sempre protegido por Deus, o fiel estaria imune a eventuais adversidades causadas por outras pessoas. Os versos são emblemáticos: "quem tocar no crente ungido vai com a cara na poeira".

Não adianta levantar contra os ungidos.

Mexer com os ungidos é brincar com fogo.

${ }^{21}$ MARTINS, Dan. Bispo Edir Macedo publica alerta a fiéis da Igreja Universal contra "profetas e profetisas”. Gospel+, São Paulo, 28 abr. 2013. Disponível em: https://noticias.gospelmais. com.br/edir-macedo-publica-alerta-a-feis-da-igreja-universal-contra-profetas-5327.html. Acesso em: 2 set. 2019.

${ }^{22}$ MACEDO, Edir. Não se deixe enganar... Blog Bispo Edir Macedo, São Paulo, 2 mar. 2017. Disponível em: https://www.universal.org/bispo-macedo/blog/. Acesso em: 2 set. 2019. 
Quem mexer com crente ungido não é brincadeira, quem tocar no crente ungido vai com a cara na poeira.

(Damares, "Não toque no ungido", grifos nossos) ${ }^{23}$

Dessa forma, dom da profecia parece se revelar num movimento constante, possibilitando uma forma de estar no mundo profundamente "mágica", numa conotaçáo a um só tempo de poder e de responsabilidade. Aduzo que a profecia é uma expressão significativa da experiência reteté em pequenas comunidades morais como a Herdeiros do Sião. Assim, argumento que a partir da expressividade das performances rituais e na mediação, a um só tempo ética e mágica, do espírito santo, as pequenas igrejas pentecostais reteté afirmam-se a partir de suas interações na própria comunidade religiosa e nas relaçóes de vizinhança no cotidiano das periferias.

\section{CONCLUSÃO}

Ao apresentar pontos de reflexão sobre a igreja pentecostal Herdeiros do Sião, a intenção foi associar a pentecostalidade praticada em tal denominação com o ethos periférico representado pelo próprio bairro de localização da igreja. Com os elementos etnográficos, observei que as pequenas denominaçóes pentecostais e seus ruidosos cultos compóem a paisagem sonora da localidade. Dessa forma, argumento que entre a Herdeiros dos Sião - e sua ritualística reteté - e o contexto do bairro em que está inserida há uma relação de afinidade eletiva (Weber, 2004) marcada pelo dinamismo e pela influência mútua entre comunidade religiosa e o contexto da favela. Uma relação, na qual as interaçóes são forjadas tanto no interior da denominação religiosas, como relaçóes entre vizinhos (Fonseca, 1991). Nesse sentido, concebo que comunidades pentecostais presentes nas favelas são estabelecidas

${ }^{23}$ NÃO toque no ungido. [S. l.: s. n.], 2013. 1 vídeo (ca. 4 min). Publicado pelo canal Jonas Alexandre. Disponível em: https://www.youtube.com/watch?v=maxqYR6D8S8. Acesso em: 2 set. 2019.

Debates do NER, Porto Alegre, Ano i9, N. 36, P. 267-305, Ago./Dez. 20 i 9 
a partir do contato com o entorno, possibilitando uma relação na qual as fronteiras são constantemente acionadas, num movimento de permanente construção entre a igreja e o contexto (Coleman, 2006).

Os rituais da igreja aqui estudada são analisados a partir da categoria reteté, expressão de grupo para se referir aos ruidosos e extáticos rituais de culto ao espírito santo marcados pela expressividade das performances corporais, que lembram uma dança giratória. Destaquei que "reteté" configura-se como uma categoria de acusação (Becker, 1985; Velho, 1978), demarcando uma complexa disputa por legitimidade dentro do campo evangélico. Nesse sentido, os protestantes históricos - vistos como racionais e teologicamente corretos - e entre os reteté, acusados de "heréticos". Tais acusaçôes relacionadas aos reteté, para além de revelar a diversidade do campo pentecostal, explicitam uma disputa, na qual a ritualística reteté - muitas vezes vivenciada em pequenas comunidades localizadas nas periferias e sem a formação de lideranças de grande vulto - é relativamente invisibilizada no espaço público. Aduzo que tais assimetrias se refletem na associação das pequenas comunidades reteté como a Herdeiros do Sião à condição periférica, também invisibilizada e estigmatizada (Machado, 2005; Sant'Ana, 2014).

Em sua associação com as periferias, as igrejas reteté foram enfatizadas por sua ênfase na dimensão sobrenatural, utilizando aqui uma categoria nativa. Percebe-se que tal dimensão é representada pelo elemento "fogo" e por categorias como manto, que seria a forma como o espírito santo se manifesta sobre o fiel, e a revelação, uma espécie de dom profético concedido a alguns, conotando um fator de distinção na comunidade religiosa. Além disso, a música expressa pelos corinhos de fogo tem grande importância na experiência.

Assim, em conclusão, argumento que a análise da pentecostalidade praticada em comunidades morais, como a Herdeiros do Sião, centradas na experiência de maravilhamento do espírito santo operando na expressividade das performances rituais reteté e na mediação, a um só tempo ética e mágica, tais igrejas florescem na vida cotidiana das periferias urbanas a partir de uma relação de afinidade eletiva do contexto em que estão inseridas, em 
um movimento constante de circulaçôes fronteiriças entre tais igrejas e os entornos nos quais se inserem.

\section{REFERENCIAS}

ALBUQUERQUE JUNIOR, Valdevino. “Dá glória e receba!”: expressão mítico-ritual nos "corinhos de fogo" no culto [neo]pentecostal. 2014. Dissertação (Mestrado em Ciência da Religião) - Universidade Federal de Juiz de Fora, Juiz de Fora, 2014.

ASAD, Talal. Formations of the Secular: Christianity, Islam, Modernity. Redwood City: Stanford University Press, 2003.

AUBRÉE, Marion. Tempo, história e nação (o curto-circuito dos pentecostais). Religiāo \& Sociedade, Rio de Janeiro, v. 17, n. 1-2, p. 77-88, 1996.

BECKER, Howard S. Outsiders. Paris: Éditions Metailié, 1985.

BECKER, Howard S. Outsiders: estudos de sociologia do desvio. Rio de Janeiro: Zahar, 2008.

BIRMAN, Patricia. Cultos de possessão e pentecostalismo no Brasil: passagens. Religião \& Sociedade, Rio de Janeiro, v. 17, n. 1-2, p. 90-109, 1996.

BIRMAN, Patricia; MACHADO, Carly. A violência dos justos: evangélicos, mídia e periferias da metrópole. Revista Brasileira de Ciências Sociais, São Paulo, v. 27, n. 80, p. 55-69, 2012. Disponível em: http://www.scielo.br/ scielo.php?. Acesso em: 2 set. 2019.

BISPO, Raphael. Os "emos das antigas" e os "posers de emo": identidades, conflitos e estigma na cena musical roqueira. Ponto Urbe: Revista do Núcleo de Antropologia Urbana da USP, São Paulo, n. 6, 2010. Disponível em: https://journals.openedition.org/pontourbe/1578. Acesso em: 2 set. 2019. BLUMENFELD, Hans. A metrópole moderna. In: DAVIS, Kingsley et al. Cidades: a urbanização da humanidade. 2. ed. Rio de Janeiro: Zahar Editores, 1972. p. 13-35. 
BOURCIER, Paul. História da dança no Ocidente. São Paulo: Martins Fontes, 2006.

COLEMAN, Simon. Materializing the self: words and gifts in the construction of charismatic Protestant identity. In: CANNELL, Fenella (ed.). The anthropology of christianity. Durham: Duke University Press, 2006. p. 163-184.

COLEMAN, Simon. Zonas fronteiriças: ética, etnografia e o cristianismo “repugnante". Debates do NER, Porto Alegre, v. 1, n. 33, p. 271-312, 2018. Disponível em: https://seer.ufrgs.br/debatesdoner/article/view/88048. Acesso em: 2 set. 2019.

CSORDAS, Thomas J. Embodiment and Cultural Phenomenology. In: WEISS, Gail; HABER, Honi (ed.). Perspectives on Embodiment. New York: Routledge, 1999. p. 143-162.

DAYRELL, Juarez. A escola "faz" as juventudes? Reflexôes em torno da socialização juvenil. Educação \& Sociedade, Campinas, v. 28, n. 100, p. 1105-1128, 2007. Disponível em: http://www.scielo.br/scielo.php?pid=S0101-73302007 000300022\&script=sci_arttext. Acesso em: 2 set. 2019.

DUARTE, Luiz Fernando Dias. Da vida nervosa nas classes trabalhadoras urbanas. Rio de Janeiro: Jorge Zahar Editor, 1988.

DUARTE, Luiz Fernando Dias. Ethos privado e justificação religiosa: negociações da reprodução na sociedade brasileira. In: HEILBORN, Maria Luiza et al. (org.). Sexualidade, familia e ethos religioso. Rio de Janeiro: Garamond, 2005. p. 137-176.

DULLO, Eduardo. Testemunho: cristão e secular. Religião \& Sociedade, Rio de Janeiro, v. 36, n. 2, p. 85-106, dez. 2016. Disponível em: http://www. scielo.br/scielo.php?pid=S0100-85872016000200085\&script=sci_abstract\& tlng=pt. Acesso em: 2 set. 2019.

DUMONT, Louis. $O$ individualismo: uma perspectiva antropológica da ideologia moderna. Rio de Janeiro: Rocco, 1985. 
EVANS-PRITCHARD, Edward Evan. Bruxaria, oráculos e magia entre os Azande. Tradução de Eduardo Viveiros de Castro. Rio de Janeiro: Zahar, 2005. FONSECA, Claudia. La religion dans la vie quotidienne d'un groupe populaire brésilien. Archives de Sciences Sociales des Religions, France, v. 73, n. 1, p. 125-139, 1991. Disponível em: https://www.persee.fr/doc/assr_03355985_1991_num_73_1_1580. Acesso em: 2 set. 2019.

FORSEY, Martin Gerard. Ethnography as participant listening. Ethnography, London, v. 11, n. 4, p. 558-572, 2010.

GIUMBELLI, Emerson. A vontade do saber: terminologias e classificaçôes sobre o protestantismo brasileiro. Religiāo \& Sociedade, Rio de Janeiro, v. 21, n. 1, p. 87-120, 2001. Disponível em: http://www.scielo.br/scielo.php? script=sci_nlinks\&ref=000140\&pid=S0100-8587200700010000700015\& lng=pt. Acesso em: 2 set. 2019.

GOFFMAN, Erving. Estigma: notas sobre a manipulação da identidade deteriorada. Rio de Janeiro: Guanabara, 1988.

GOLDMAN, Marcio. A construção ritual da pessoa: a possessão no candomblé. Religião \& Sociedade, Rio de Janeiro, v. 12, n. 1, p. 22-54, 1985. GUERREIRO, Clayton. Do “circo" à "macumba” pentecostal: sobre categorias acusatórias e justificações. In: ARAÚJO, Melvina; CUNHA, Christina Vital (org.). Religiāo e Conflito. Curitiba: Prisma, 2016. p. 195-216.

GUERREIRO, Clayton. "Hoje à noite vai ter reteté, pô!”: evidências de conflitos cotidianos em rituais pentecostais. Debates do NER, Porto Alegre, v. 2, n. 34, p. 123-154, 2018. Disponível em: https://seer.ufrgs.br/debatesdoner/article/view/89949. Acesso em: 2 set. 2019.

INSTITUTO BRASILEIRO DE GEOGRAFIA E ESTATÍSTICA (IBGE). Censo 2010. Rio de Janeiro: IBGE, 2010. Disponível em: http://www. censo2010.ibge.gov.br/. Acesso em: 2 set. 2019.

KOWARICK, Lúcio. Escritos urbanos. São Paulo: Editora 34, 2000. 
LANGDON, Esther Jean Matteson (org.). Xamanismo no Brasil: novas perspectivas. Florianópolis: EDUFSC, 1996.

LE GOFF, Jacques. Por amor às cidades. São Paulo: Unesp, 1998.

LEWIS, Ioan M. Exxtase religioso: um estudo antropológico da possessão por espírito e do xamanismo. São Paulo: Perspectiva, 1971.

LOPES, Artur Costa. O forró como gênero transversal entre umbanda, catolicismo e pentecostalismo. In: SIMPÓSIO BRASILEIRO DE PÓS-GRADUANDOS EM MÚSICA, 4., 2016, Rio de Janeiro. Anais [...]. Rio de Janeiro: Unirio, 2016. p. 607-616. Disponível em: http://www.seer. unirio.br/index.php/simpom/article/view/5715. Acesso em: 2 set. 2019.

LÖWY, Michael. Sobre o conceito de afinidade eletiva em Max Weber. Tradução de Lucas Amaral de Oliveira e Mariana Toledo Ferreira. Plural: Revista de Ciências Sociais, São Paulo, v. 17, n. 2, p. 129-142, 2011. Disponível em: http://www.periodicos.usp.br/plural/article/view/74543. Acesso em: 2 set. 2019.

MACHADO, Carly. Evangélicos, mídias e periferias urbanas: questōes para um diálogo sobre religião, cidade, nação e sociedade civil no Brasil contemporâneo. Debates do NER, Porto Alegre, v. 1, n. 33, p. 58-80, 2018. Disponível em: https://www.seer.ufrgs.br/debatesdoner/article/view/88039. Acesso em: 2 set. 2019.

MACHADO, Maria das Dores Campos. Representaçóes e relaçóes de gênero nos grupos pentecostais. Revista Estudos Feministas, Florianópolis, v. 13, n. 2, p. 387-396, 2005. Disponível em: http://www.scielo.br/scielo. php?pid=S0104-026X2005000200012\&script=sci_arttext\&tlng=pt. Acesso em: 2 set. 2019.

MAFRA, Clara. Na posse da palavra: religiáo, conversão e liberdade pessoal em dois contextos nacionais. 1999. Tese (Doutorado em Antropologia Social) - Museu Nacional, Universidade Federal do Rio de Janeiro, Rio de Janeiro, 1999. 
MAFRA, Clara. O problema da formação do "cinturão pentecostal" em uma metrópole da América do Sul. Interseçôes: Revista de Estudos Interdisciplinares, Rio de Janeiro, v. 13, n. 1, p. 136-153, 2011. Disponível em: https://www.e-publicacoes.uerj.br/index.php/intersecoes/article/view/4609. Acesso em: 2 set. 2019.

MAFRA, Clara. Relatos compartilhados: experiências de conversão ao pentecostalismo entre brasileiros e portugueses. Mana, Rio de Janeiro, v. 6 , n. 1, p. 57-86, 2000.

MAGGIE, Yvonne. Guerra de orixá: um estudo de ritual e conflito. Rio de Janeiro: Jorge Zahar Editor, 1975.

MARIANO, Ricardo. Efeitos da secularização do Estado, do pluralismo e do mercado religiosos sobre as igrejas pentecostais. Civitas: Revista de Ciências Sociais, Porto Alegre, v. 3, n. 1, p. 111-125, 2003. Disponível em: https://www.redalyc.org/pdf/742/74230106.pdf. Acesso em: 2 set. 2019.

NOVAES, Regina. Juventude, religião e espaço público: exemplos "bons para pensar" tempos e sinais. Religiáo \& Sociedade, Rio de Janeiro, v. 32, n. 1, p. 184-208, 2012.

NOVAES, Regina. Os jovens, os ventos secularizantes e o espírito do tempo. In: ENCONTRO ANUAL DA ANPOCS, 30., 2006, Caxambu. Anais [...]. São Paulo: ANPOCS, 2006. Disponível em: http://anpocs.org/index.php/ papers-30-encontro/gt-26/gt17-17/3392-rnovaes-os-jovens/file. Acesso em: 2 set. 2019.

OOSTERBAAN, Martijn. Sonic supremacy: sound, space and charisma in a favela in Rio de Janeiro. Critique of Anthropology, United Kingdom, v. 29, n. 1, p. 81-104, 2009. Disponível em: https://journals.sagepub.com/ doi/abs/10.1177/0308275X08101028. Acesso em: 2 set. 2019.

OOSTERBAAN, Martijn. Spiritual attunement: pentecostal radio in the soundscape of a favela in Rio de Janeiro. Social Text, Durham, v. 26, n. 3, p. 123-145, 2008. 
PEIRANO, Mariza. Etnografia não é método. Horizontes Antropológicos, Porto Alegre, ano 20, n. 42, p. 377-391, jul./dez. 2014.

PEIRANO, Mariza (org.). O dito e o feito: ensaios de antropologia dos rituais. Rio de Janeiro: Relume Dumará, 2002.

PEREIRA, Réia Sílvia Gonçalves. Fé em Deus, DJ: funk e pentecostalismo entre jovens das camadas populares. 2014. Dissertação (Mestrado em Ciências Sociais) - Universidade Federal do Espírito Santo, Vitória, 2014.

PEREIRA, Réia Sílvia Gonçalves. "Juventude é curtição, o problema é se Jesus voltar": cultura funk, pentecostalismo e juventudes nas camadas populares. Religião \& Sociedade, Rio de Janeiro, v. 38, n. 3, p. 41-62, 2018. Disponível em: http://www.scielo.br/scielo.php?script=sci_arttext \&pid=S0100-85872018000300041. Acesso em: 2 set. 2019.

ROUGET, Gilbert. La musique et la transe. Paris: Gallimard, 1980.

SANT'ANA, Raquel. A nação cujo Deus é o Senhor: a imaginação de uma coletividade "evangélica" a partir da Marcha para Jesus. 2017. Tese de Doutorado (Doutorado em Antropologia Social) - Universidade Federal do Rio de Janeiro, Rio de Janeiro, 2017.

SANT'ANA, Raquel. O som da Marcha: evangélicos e espaço público na Marcha para Jesus. Religião \& Sociedade, Rio de Janeiro, v. 34, n. 2, p. 210-231, dez. 2014. Disponível em: http://www.scielo.br/scielo.php?script =sci_abstract\&pid=S0100-85872014000200210\&lng=en\&nrm=iso\&tlng=pt. Acesso em: 2 set. 2019.

SANTOS, Milton. Manual de geografia urbana. São Paulo: HUCITEC, 1981. SCHAFER, Raymond Murray. A afinação do mundo. São Paulo: UNESP, 1997.

SELLIER, Henri. Les banlieues urbaines. In: RONCAYOLO, Marcel; PAQUOT, Thierry (ed.). Villes \& civilisation urbaine, XVIIIe-XXe siècle. Paris: Larousse, 1992. p. 453-466. 
SILVEIRA, Emerson José Sena da. Categorias de acusação e campo religioso brasileiro: notas sobre manipulaçóes da identidade e fronteiras móveis. In: ANDRADE, Péricles (org.). Polifonia do sagrado: pesquisas em ciências da religião no Brasil. São Cristóvão: UFS, 2015. p. 31-45.

SPOSITO, Marília Pontes. A ilusão fecunda: a luta por educação nos movimentos populares. São Paulo: HUCITEC, 1993.

TURNER, Victor W. Estrutura e antiestrutura. Petrópolis, RJ: Editora Vozes, 1974.

VALLADARES, Licia do Prado. A invenção da favela: do mito de origem a favela.com. Rio de Janeiro: FGV Editora, 2008.

VELHO, Gilberto. Nobres \& anjos: um estudo de tóxicos e hierarquia. Rio de Janeiro: Editora FGV, 2008.

VELHO, Gilberto. Observando o familiar. In: VELHO, Gilberto. Individualismo e cultura: notas para uma antropologia da sociedade contemporânea. Rio de Janeiro: Zahar, 1978. p. 123-132.

WEBER, Max. A ética protestante e o espírito do capitalismo. São Paulo: Companhia das Letras, 2004.

Recebido em: 18/09/2019

Aprovado em: 07/10/2019 
